Please do not remove this page

RMIT

UNIVERSITY

\title{
Double dropping down under: Correlates of simultaneous consumption of two ecstasy pills in a sample of Australian outdoor music festival attendees
}

Grigg, Jodie; Barratt, Monica; Lenton, Simon

https://researchrepository.rmit.edu.au/esploro/outputs/9921861063401341/filesAndLinks?institution=61RMIT_INST\&index=null

Grigg, J., Barratt, M., \& Lenton, S. (2018). Double dropping down under: Correlates of simultaneous consumption of two ecstasy pills in a sample of Australian outdoor music festival attendees. Drug and Alcohol Review, 37(7), 851-855. https://doi.org/10.1111/dar.12843

Document Version: Accepted Manuscript

Published Version: https://doi.org/10.1111/dar.12843

Repository homepage: https://researchrepository.rmit.edu.au

(C) 2018 Australasian Professional Society on Alcohol and other Drugs

Downloaded On 2023/04/26 21:23:29 +1000 
This is the peer reviewed version of the following article:

Grigg, J., Barratt, M. J., \& Lenton, S. (2018). Double dropping down under: Correlates of simultaneous consumption of two ecstasy pills in a sample of Australian outdoor music festival attendees. Drug and Alcohol Review, 37, 851855.

which has been published in final form at https://doi.org/10.1111/dar.12843

This article may be used for non-commercial purposes in accordance with Wiley Terms and Conditions for Use of Self-Archived Versions. 
Double dropping down under: Correlates of simultaneous consumption of two ecstasy pills in a sample of Australian outdoor music festival attendees

RUNNING TITLE: Double dropping at music festivals

Jodie Grigg, PhD Candidate, National Drug Research Institute, Curtin University.

Monica J. Barratt, PhD, Research Fellow, Drug Policy Modelling Program, National Drug and Alcohol Research Centre, UNSW Australia; National Drug Research Institute, Curtin University; Behaviours and Health Risks Program, Burnet Institute.

Simon Lenton, Professor and Director, National Drug Research Institute, Curtin University.

Corresponding author:

Jodie Grigg

GPO Box U1987

Perth WA 6845

Email: Jodie.grigg@postgrad.curtin.edu.au 


\begin{abstract}
INTRODUCTION AND AIMS: The term 'double dropping' refers to a person consuming two drugs simultaneously, typically two ecstasy pills. This practice has been reported in numerous countries, including Australia; however, the prevalence and correlates of double dropping among ecstasy users is unknown. Double dropping is particularly risky when adulteration of 'ecstasy' with novel substances and higher dosages of MDMA in pure ecstasy pills have both been increasingly reported. This paper investigates the prevalence and correlates of double dropping in a purposive sample of Australian festival-goers who used ecstasy at the last festival they attended.
\end{abstract}

DESIGN AND METHODS: A web survey was completed by almost 2000 Australian festival-goers. The analytic sample $(n=777)$ was $59 \%$ male and had a median age of 20 years (IQR=19-23).

RESULTS: Almost half (48\%) of respondents who used ecstasy pills reported double dropping in association with the last festival attended. Multivariable logistic regression found respondents who were younger, male, more frequent ecstasy users, more frequent festival-goers, had a preference for electronic dance music, attended a multi-day festival and used ecstasy in pill form were at greater odds of reporting double dropping at the last festival attended.

DISCUSSION AND CONCLUSIONS: Double dropping was a commonly reported practice among festival-goers in this purposive sample. While this practice may reflect historically low-dose ecstasy pills in Australia, the changing contexts of novel drugs and increasing MDMA purity may warrant consideration of harm-reduction interventions and drug-checking services which could help festivalgoers make more informed decisions about drug dosage.

Keywords: ecstasy, drug users, double dropping, music festivals, harm reduction, pill testing

Word count abstract $=247$ (Maximum of 250)

Word count body of paper $=1500$ (Maximum of 1500)

Number of references $=28$ (Maximum of 30$)$

Number of tables $=1($ Maximum of 2$)$ 


\section{Introduction}

The term 'double dropping' refers to the consumption of two drugs simultaneously, typically two ecstasy pills. This practice has been reported in online ecstasy user reports (1), drug-related media (26) and qualitative drug-related literature (7). While national monitoring systems in Australia suggest it is common for ecstasy users to consume multiple pills in one session (median $=4$ for heavy sessions) (8), the prevalence of double dropping among ecstasy users is unknown.

This practice is a public-health concern. Most ecstasy consumers are unaware of what drugs are contained within their 'ecstasy' pills/caps, and if they do contain only MDMA, consumers are also unlikely to know the dosage. New Psychoactive Substances (NPS) are newly misused or newly synthesised drugs that pose a similar public-health threat to established drugs (9). Misrepresentation of NPS as ecstasy is particularly concerning when considering the differences in drug potency, onset of action and effects, and has been linked to hospitalisations and deaths in Australia $(10,11)$. Furthermore, the risk of taking multiple strong doses of MDMA simultaneously has increased: Europe has reported increased availability of higher-dose ecstasy pills (over 100mg) and 'super pills' (up to 340mg) (12). The availability and consumption of ecstasy capsules in Australia which contain MDMA in crystal or powder forms has also increased (8). These capsules could contain higher MDMA doses than pills/tablets, given crystal and powder forms do not require binding agents or fillers. While pure MDMA may be recognised as one of the least dangerous prohibited substances (13), higher doses do increase risk despite MDMA dosage not following a typical dose-response curve (14) and pure MDMA overdoses do occur (15). Thus, shifting purity trends could place ecstasy users who continue to double drop at greater risk of overdose.

Given the dearth of information about the practice of 'double dropping' in Australia, we seek to understand the prevalence and correlates of this practice in a self-selected sample. Identifying correlates may assist in targeting interventions to prevent this practice. Candidate variables include: age (greater risk implications for younger people, neurotoxicity in the developing brain $(16,17)$ ), gender (biological differences may heighten risk for females $(18,19)$ ), jurisdiction (awareness of 
jurisdictional differences can help inform/target interventions), ecstasy form/s consumed (disparate perceptions of the purity/potency of different forms may influence dosing decisions), frequency of ecstasy use (perceived tolerance may influence dosing decisions), frequency of festival attendance (indication of involvement in the scene), preferred musical genre at festivals (preference for electronic dance music $(E D M)$ is associated with increased levels of drug use $(7,20))$ and the type of festival attended (different event characteristics may result in different patterns of use).

\section{Aim}

This paper investigates the prevalence and correlates of double dropping in a purposive sample of Australian festival-goers who used ecstasy at the last festival they attended.

\section{Methods}

A web survey was developed using Qualtrics (35). Responses were anonymised to ensure no personal information, such as IP addresses, was collected. A prize draw for a $\$ 500$ e-gift card was offered. The survey ran from May-July 2016 and received 3529 responses. The eligibility criteria were: aged 16 and older, lived in Western Australia or Victoria for the preceding 12 months and attendance at $>1$ music festival in the preceding 12 months. After deleting ineligible cases, duplicate cases, and cases where less than $50 \%$ questions were completed, 1967 responses remained. This final sample was primarily recruited through targeted Facebook ads (89\%), and by snowballing and music news articles (each 5\%). For this paper, all respondents who had not completed the risk behaviours question (Did you do any of the following in association with the last festival you attended?) and had not used ecstasy pills and/or caps at the last festival were excluded, resulting in an analytic sample of 777 . Ethics approval was received by the Curtin University Human Research Ethics Committee (HR144/2015).

\section{Data analysis}

Bivariable and multivariable logistic regressions determined unique predictors of reported double dropping at the last festival attended. Candidate variables in multivariable regression model included demographic or drug use variables with bivariable tests $p<.25(21)$. When running a complete case 
analysis, $34 \%(n=261)$ of the cases were missing. Almost all missing cases $(98 \%, n=257)$ came from one variable 'frequency of general ecstasy use'. Missing data for this variable were deemed as missing at random given they were most likely related to respondents not realising they had to scroll right when completing the survey via mobile phone. The multiple imputation (MI) function within SPSS was used to generate 34 imputed datasets, corresponding to the percentage of missing cases (22). All analyses were conducted using SPSS Statistics 23 for Windows (23).

\section{Results}

\section{Demographics}

The median age of respondents was 20 years $(\mathrm{IQR}=19-23$, range $=16-47)$ and more than half were male (59\%) ( $n=777)$. See Table S1 for full demographic statistics.

\section{Prevalence of double dropping}

Of those who used ecstasy in pill/tablet form at the last festival they attended ( $\mathrm{n}=591)$, almost half (48\%) reported double dropping. In contrast, among capsule only users $(\mathrm{n}=186)$, approximately onequarter $(28 \%)$ reported double dropping.

\section{Correlates of double dropping}

In the multivariable model (see Table 1), self-reporting of double dropping was uniquely predicted by age, gender, form used, frequency of general ecstasy use, the number of recent festivals attended, preferred musical genre and the festival type attended.

While confidence interval trends were largely consistent with MI $(n=773)$ and without $(n=516)$, the intervals for the odds of double dropping among those who reported more frequent general ecstasy use were substantially higher without MI. This suggests the strength of the correlation between more frequent use of ecstasy and double dropping may be underestimated by the MI model. The complete case analysis is presented in Table $\mathrm{S} 2$.

[Insert Table 1] 


\section{Discussion}

Double dropping was a common drug practice in this sample, reported by half of respondents who used ecstasy pills at the last festival. Multivariable logistic regression identified seven unique predictors of this practice. Two predictors warrant further discussion. Firstly, the finding that more frequent ecstasy users were at significantly greater odds of reporting double dropping may reflect a perceived tolerance to MDMA and/or a level of complacency towards dosing, which could be problematic in an unpredictable and shifting drug market. Secondly, the finding that capsule users were less likely to report double dropping than pill users could reflect a perception that capsules are more potent than pills (8). However, it is possible some consumers purchased crystalline or powder MDMA then packaged capsules themselves. A perceived increase in control over dosage could reduce the desire to double drop, or in contrast, may increase confidence in double dropping.

This study's findings, in combination with current market trends, suggest it may be worth implementing a targeted awareness campaign in Australia. Findings presented here may also warrant consideration of field laboratories which can chemically analyse both the content and dose of drugs. While debate over drug checking continues in Australia (24), such services have successfully operated in Europe for decades (25). High-dose MDMA pills are identified and warnings disseminated to help guide consumers in those countries towards more sensible dosing strategies (12).

\section{Limitations}

Like other studies of hidden populations, this study recruited a purposive sample, rather than a probability sample (26). Given the sampling methods used, findings cannot be seen to estimate the prevalence of double dropping in the wider population of people who use ecstasy at festivals. Another limitation relates to the wording of the response option for 'double dropping (took two pills at the same time)'. Some respondents may have included other drugs which come in pill form, although less than $4 \%$ reported concurrent use of such drugs. Additionally, given the online sampling method, it was impossible to objectively verify responses regarding drug use (e.g. via urine screening) or festival attendance. However, web survey methodology offered many advantages (27), such as being entirely 
anonymous, enabling thousands to participate, and avoiding on-site sampling limitations (e.g. selection bias; inability to report on what happened later in the day). Most epidemiological studies of people who use drugs must rely on self-report, and such reports can typically be trusted especially under conditions of anonymity (28). While there was an incentive to participate (a lottery prize draw), the survey itself was lengthy (median=23 minutes), so it is unlikely respondents completed it with false data simply to enter the draw. To counteract this possibility, respondents who reported attending events which could not be verified were excluded.

\section{Conclusions}

Double dropping was identified as a common risk behaviour among Australian ecstasy-using festivalgoers. Respondents who were younger, male, more frequent ecstasy users, more frequent festivalgoers, preferred EDM, attended a multi-day festival and used ecstasy in pill/tablet forms were more likely to report double dropping. These findings have implications for raising awareness about the risks associated with double dropping, particularly in the current drug market, and for consideration of a drug checking trial to help festival-goers make more informed decisions. Future research investigating double dropping of different forms of ecstasy, in different recreational settings and countries, may be beneficial in helping improve our understanding of this practice. 


\section{Acknowledgements}

Thank you to all the festival-goers who generously donated their time to complete the online survey. This doctoral research was funded by a scholarship from the Australian Government Department of Health. Monica Barratt is supported by a fellowship from the National Health and Medical Research Council (APP1070140). The National Drug and Alcohol Research Centre and the National Drug Research Institute are supported by funding from the Australian Government under the Drug and Alcohol Program Fund.

\section{Declaration of interests}

There are no relevant interests to declare. 


\section{References}

1. Enlighten. Pillreports Ecstasy Test Results Database 2017 [Available from:

http://www.pillreports.net/.

2. Davies K. Drug warning at inquest into death of young mum. Evening Chronicle [Internet]. 2013 10/09/2014. Available from: http://www.chroniclelive.co.uk/news/north-east-news/gemmahurst-drug-warning-inquest-6384683.

3. ABC. Potent ecstasy sparks concerns for young Australians. ABC News [Internet]. 2014 14/02/2917. Available from: http://www.abc.net.au/news/2014-01-04/potent-ecstasy-sparks-concernsfor-young-australians $/ 5184700$.

4. Mullally U. Warning about PMA/PMMA drug after six deaths. Irish Times [Internet]. 2014 14/02/2017. Available from: http://www.irishtimes.com/news/health/warning-about-pma-pmma-drugafter-six-deaths-in-ireland-1.1832118.

5. Sargeant C. Heads up m8s, there's a dangerously strong batch of ecstasy garn around $\mathrm{rn}$. Pedestrian [Internet]. 2017 31/01/2017. Available from: https://www.pedestrian.tv/news/arts-andculture/heads-up-m8s-theres-a-dangerously-strong-batch-of-/5de2ce4d-bc37-4922-87802d21ee304ee0.htm.

6. Roseingrave L. Teen died after taking ecstasy for first time. Irish Examiner [Internet]. 2010 14/02/2017. Available from: http://www.irishexaminer.com/ireland/teen-died-after-taking-ecstasyfor-first-time-136953.html.

7. Duff C, Johnston J, Moore D, Goren N. Dropping, connecting, playing and partying: Exploring the social and cultural contexts of ecstasy and related drug use in Victoria. Melbourne, Australia: Premier's Drug Prevention Council; 2007.

8. Uporova J, Karlsson A, Sutherland R, Burns L. Australian trends in ecstasy and related drug markets 2017: Findings from the Ecstasy and related Drugs Reporting System (EDRS). Sydney: National Drug and Alcohol Research Centre, UNSW Australia; 2018.

9. Dargan P. Novel psychoactive substances: Classification, pharmacology and yoxicology. Wood D, editor. Burlington: Elsevier Science; 2013.

10. Morgans J. NBOMe in Australia: Everything we know about the drug and why it's killing people. VICE [Internet]. 2017 21/03/2017. Available from:

https://www.vice.com/en_au/article/nbome-in-australia-everything-we-know-about-what-it-is-andwhy-its-killing-people?utm_source=vicefblocalau.

11. Evans J. Woman hospitalised with seizures after fake MDMA discovered in Canberra. ABC News [Internet]. 2017 24/02/2017. Available from: http://www.abc.net.au/news/2017-02-24/womanhospitalised-after-taking-fake-mdma-in-canberra/8301366.

12. Mounteney J, Griffiths P, Bo A, Cunningham A, Matias J, Pirona A. Nine reasons why ecstasy is not quite what it used to be. International Journal of Drug Policy. 2018;51:36-41.

13. Nutt DJ, King LA, Phillips LD. Drug harms in the UK: A multicriteria decision analysis. The Lancet. 2010;376(9752):1558-65.

14. Mueller M, Peters FT, Maurer HH, McCann UD, Ricaurte GA. Nonlinear pharmacokinetics of ( \pm )3,4-Methylenedioxymethamphetamine (MDMA, "Ecstasy") and its major metabolites in squirrel monkeys at plasma concentrations of MDMA that develop after typical psychoactive doses. $\mathrm{J}$ Pharmacol Exp Ther. 2008;327(1):38-44.

15. De Letter EA, Piette MHA, Lambert WE, Cordonnier JACM. Amphetamines as potential inducers of fatalities: A review in the district of Ghent from 1976-2004. Med Sci Law. 2006;46(1):37. 16. Winters KC, Arria A. Adolescent brain development and drugs. The Prevention Researcher. 2011;18(2):21-4.

17. Jacobsen LK, Mencl WE, Pugh KR, Skudlarski P, Krystal JH. Preliminary evidence of hippocampal dysfunction in adolescent MDMA ("ecstasy") users: possible relationship to neurotoxic effects. Psychopharmacology. 2004;173(3):383-90.

18. Liechti ME, Gamma A, Vollenweider FX. Gender differences in the subjective effects of MDMA. Psychopharmacology (Berl). 2001;154(2):161-8.

19. Simmler LD, Hysek CM, Liechti ME. Sex differences in the effects of MDMA (ecstasy) on plasma copeptin in healthy subjects. J Clin Endocrinol Metab. 2011;96(9):2844-50. 
20. Lim MSC, Hellard ME, Hocking JS, Aitken CK. A cross-sectional survey of young people attending a music festival: Associations between drug use and musical preference. Drug Alc Rev. 2008;27:439-41.

21. Hosmer DW, Lemeshow S. Applied logistic regression. 2nd ed. New York, NY: Wiley; 2000. 22. Manly CA, Wells RS. Reporting the use of multiple imputation for missing data in higher education research. Research in Higher Education. 2015;56(4):397-409.

23. IBM Corp. IBM SPSS Statistics for Windows, Version 23.0. Armonk, NY: IBM Corp.; 2015. 24. Schneider J, Galettis P, Williams M, Lucas C, Martin JH. Pill testing at music festivals: can we do more harm? Intern Med J. 2016;46(11):1249-51.

25. Brunt TM, Nagy C, Bucheli A, Martins D, Ugarte M, Beduwe C, et al. Drug testing in Europe: monitoring results of the Trans European Drug Information (TEDI) project. Drug Testing and Analysis. 2017;9:188-98.

26. Barratt MJ, Ferris JA, Lenton S. Hidden populations, online purposive sampling, and external validity: Taking off the blindfold. Field Methods. 2015;27:3-21.

27. Tuten TL. Conducting online surveys. In: Gosling SD, Johnson JA, editors. Advanced methods for conducting online behavioral research. Washington, DC: American Psychological Association; 2010. p. 179-92.

28. Darke S. Self-report among injecting drug users: a review. Drug Alcohol Depend. 1998;51(3):253-63; discussion 67-8. 
Page 11 of 12

Table 1: Predictors of 'double dropping' among those who used ecstasy pills and/or capsules at the last festival (multivariable logistic regression)

\begin{tabular}{|c|c|c|c|c|c|c|c|c|c|c|}
\hline \multirow[b]{2}{*}{ Variable } & \multirow[b]{2}{*}{ Level } & \multirow[b]{2}{*}{$n$} & \multirow{2}{*}{$\begin{array}{c}\text { Did double } \\
\text { drop } \\
43.5 \%\end{array}$} & \multirow{2}{*}{$\begin{array}{c}\text { Did not } \\
\text { double drop } \\
56.5 \%\end{array}$} & \multicolumn{3}{|c|}{ Bivariable } & \multicolumn{3}{|c|}{ Multivariable } \\
\hline & & & & & OR & 95\% CI & $P$-value & AOR & $95 \%$ CI & $P$-value \\
\hline \multirow{5}{*}{ Age } & 16-17 years old & 103 & 53 & 47 & 2.714 & $1.401-5.258$ & 0.003 & 3.308 & $1.576-6.946$ & 0.002 \\
\hline & $18-19$ years old & 207 & 54 & 46 & 2.738 & $1.500-4.999$ & 0.001 & 2.647 & $1.365-5.132$ & 0.004 \\
\hline & 20-21 years old & 194 & 40 & 60 & 1.593 & $0.867-2.926$ & 0.134 & 1.256 & $0.646-2.442$ & 0.501 \\
\hline & $22-25$ years old & 205 & 36 & 64 & 1.310 & $0.713-2.405$ & 0.384 & 1.020 & $0.527-1.977$ & 0.952 \\
\hline & 26 years and over & 64 & 30 & 70 & 1.000 & & & 1.000 & & \\
\hline \multirow{2}{*}{ Gender } & Male & 459 & 51 & 49 & 2.265 & $1.678-3.056$ & $<0.001$ & 2.477 & $1.766-3.475$ & $<0.001$ \\
\hline & Female & 314 & 32 & 68 & 1.000 & & & 1.000 & & \\
\hline \multirow{2}{*}{ State } & WA & 405 & 43 & 57 & 0.938 & $0.705-1.247$ & 0.659 & & & \\
\hline & VIC & 368 & 44 & 56 & 1.000 & & & \# & & \\
\hline \multirow{3}{*}{ Ecstasy form } & Pills and caps & 187 & 66 & 34 & 5.072 & $3.263-7.883$ & $<0.001$ & 3.701 & $2.311-5.928$ & $<0.001$ \\
\hline & Pills only & 400 & 40 & 60 & 1.718 & $1.178-2.506$ & 0.005 & 1.698 & $1.122-2.568$ & 0.012 \\
\hline & Caps only & 186 & 28 & 72 & 1.000 & & & 1.000 & & \\
\hline \multirow{4}{*}{$\begin{array}{l}\text { Frequency of general } \\
\text { ecstasy use }\end{array}$} & 1/week & 97 & 62 & 38 & 5.160 & $2.928-9.091$ & $<.001$ & 3.645 & $1.937-6.862$ & $<0.001$ \\
\hline & $1 /$ month & 282 & 48 & 53 & 2.881 & $1.827-4.544$ & $<.001$ & 2.296 & $1.382-3.812$ & 0.001 \\
\hline & Every few months & 256 & 43 & 57 & 2.359 & $1.485-3.749$ & $<.001$ & 2.270 & $1.368-3.769$ & 0.002 \\
\hline & $1-2 /$ year & 138 & 24 & 76 & 1.000 & & & & & \\
\hline \multirow{3}{*}{$\begin{array}{l}\text { Total recent festivals } \\
\text { attended }\end{array}$} & $1-2$ & 274 & 39 & 61 & 0.613 & $0.427-0.881$ & 0.008 & 0.622 & $0.410-0.946$ & 0.026 \\
\hline & $3-4$ & 286 & 43 & 57 & 0.723 & $0.506-1.033$ & 0.075 & 0.660 & $0.444-0.982$ & 0.040 \\
\hline & 5 or more & 213 & 51 & 49 & 1.000 & & & 1.000 & & \\
\hline \multirow{3}{*}{$\begin{array}{l}\text { Favourite festival } \\
\text { genre was electronic } \\
\text { dance music }\end{array}$} & No & 210 & 31 & 69 & 0.493 & $0.349-0.697$ & $<0.001$ & 0.641 & $0.437-0.942$ & 0.023 \\
\hline & No favourite genre & 125 & 47 & 53 & 0.962 & $0.646-1.432$ & 0.848 & 1.230 & $0.790-1.916$ & 0.360 \\
\hline & Yes & 438 & 48 & 52 & 1.000 & & & 1.000 & & \\
\hline
\end{tabular}


Page 12 of 12

\begin{tabular}{|c|c|c|c|c|c|c|c|c|c|c|}
\hline \multirow{3}{*}{ Festival type } & \multirow{3}{*}{$\begin{array}{c}\text { One day } \\
\text { Inconsistent } \\
\text { selection } \\
\text { Multi-day }\end{array}$} & 529 & 41 & 59 & 0.752 & $0.540-1.046$ & 0.090 & 0.596 & $0.402-0.884$ & 0.010 \\
\hline & & 50 & 46 & 54 & 0.906 & $0.486-1.690$ & 0.757 & 0.779 & $0.384-1.582$ & 0.489 \\
\hline & & 194 & 49 & 52 & 1.000 & & & 1.000 & & \\
\hline
\end{tabular}

\# Dropped from the multivariable model because $\mathrm{p}>.25$

Model $\chi^{2}(16)=152.821, \mathrm{p}<0.001$. Adjusted R square $=0.179($ Cox \& Snell), 0.241 (Nagelkerke). Hosmer-Lemeshow goodness of fit test, $\mathrm{p}=0.110, n=773$. 
Table S1: Demographic characteristics of festival-goers who used ecstasy pills and/or caps

\begin{tabular}{|c|c|c|c|c|c|c|c|c|}
\hline \multirow[b]{2}{*}{ Variable } & \multirow[b]{2}{*}{ Level } & \multirow[b]{2}{*}{$n$} & \multirow{2}{*}{$\begin{array}{c}\text { Did double } \\
\text { drop } \\
43.5 \%\end{array}$} & \multirow{2}{*}{$\begin{array}{c}\text { Did not } \\
\text { double drop } \\
56.5 \%\end{array}$} & \multirow{2}{*}{$\begin{array}{c}\text { Total } \\
\%\end{array}$} & \multicolumn{3}{|c|}{ Bivariable } \\
\hline & & & & & & OR & $95 \% \mathrm{CI}$ & $\begin{array}{c}P \text { - } \\
\text { value }\end{array}$ \\
\hline Age (median) & Continuous & 777 & 20 & 21 & 20 & 0.937 & $0.900-0.976$ & 0.002 \\
\hline \multirow{5}{*}{ Age categories } & $16-17$ years old & 104 & 53.8 & 46.2 & 13.4 & 2.825 & $1.461-5.460$ & 0.002 \\
\hline & $18-19$ years old & 208 & 53.4 & 46.6 & 26.8 & 2.770 & $1.521-5.048$ & 0.001 \\
\hline & 20-21 years old & 194 & 40.2 & 59.8 & 25.0 & 1.628 & $0.887-2.986$ & 0.115 \\
\hline & $22-25$ years old & 206 & 35.9 & 64.1 & 26.5 & 1.357 & $0.741-2.487$ & 0.323 \\
\hline & 26 years and over & 65 & 29.2 & 70.8 & 8.4 & 1.000 & & \\
\hline \multirow{2}{*}{ Gender } & Male & 459 & 51.4 & 48.6 & 59.4 & 2.265 & $1.678-3.056$ & $<0.001$ \\
\hline & Female & 314 & 31.8 & 68.2 & 40.6 & 1.000 & & \\
\hline \multirow{2}{*}{ State } & WA & 406 & 42.9 & 57.1 & 52.3 & 0.947 & $0.713-1.257$ & 0.705 \\
\hline & VIC & 371 & 44.2 & 55.8 & 47.7 & 1.000 & & \\
\hline \multirow{2}{*}{ Sexual identity } & Other & 73 & 49.3 & 50.7 & 10.4 & 1.284 & $0.791-2.086$ & 0.321 \\
\hline & Heterosexual & 631 & 43.1 & 56.9 & 89.6 & 1.000 & & \\
\hline \multirow{2}{*}{ Marital status } & Never married & 657 & 44.6 & 55.4 & 93.3 & 1.717 & $0.912-3.232$ & 0.094 \\
\hline & Married & 47 & 31.9 & 68.1 & 6.7 & 1.000 & & \\
\hline \multirow{2}{*}{ ATSI } & No & 692 & 43.6 & 56.4 & 98.9 & 0.774 & $0.192-3.121$ & 0.719 \\
\hline & Yes & 8 & 50.0 & 50.0 & 1.1 & 1.000 & & \\
\hline \multirow{2}{*}{$\begin{array}{l}\text { Born in } \\
\text { Australia }\end{array}$} & Yes & 632 & 44.5 & 55.5 & 90.2 & 1.324 & $0.794-2.208$ & 0.282 \\
\hline & No & 69 & 37.7 & 62.3 & 9.8 & 1.000 & & \\
\hline \multirow{2}{*}{ Location } & City/suburbs & 604 & 43.2 & 56.8 & 85.8 & 0.858 & $0.561-1.312$ & 0.480 \\
\hline & Regional/remote & 100 & 47.0 & 53.0 & 14.2 & 1.000 & & \\
\hline \multirow{4}{*}{ Accommodation } & Own & 57 & 50.9 & 49.1 & 8.1 & 1.036 & $0.270-3.971$ & 0.959 \\
\hline & Rented & 225 & 34.7 & 65.3 & 32.1 & 0.531 & $0.149-1.889$ & 0.328 \\
\hline & Family & 410 & 47.6 & 52.4 & 58.4 & 0.907 & $0.259-3.180$ & 0.879 \\
\hline & Other & 10 & 50.0 & 50.0 & 1.4 & 1.000 & & \\
\hline \multirow{2}{*}{$\begin{array}{l}\text { Completed Year } \\
12 \text { or equivalent } \\
\text { (>17 years) }\end{array}$} & No & 55 & 56.4 & 43.6 & 9.0 & 1.858 & $1.062-3.250$ & 0.030 \\
\hline & Yes & 556 & 41.0 & 59.0 & 91.0 & 1.000 & & \\
\hline \multirow{2}{*}{$\begin{array}{l}\text { Trade or tertiary } \\
\text { qualification } \\
\text { (>17 years) }\end{array}$} & No & 329 & 43.8 & 56.2 & 53.7 & 1.127 & $0.817-1.555$ & 0.465 \\
\hline & Yes & 284 & 40.8 & 59.2 & 46.3 & 1.000 & & \\
\hline \multirow{5}{*}{$\begin{array}{l}\text { Employment } \\
\text { status }\end{array}$} & Full-time work & 228 & 43.9 & 56.1 & 32.9 & 0.888 & $0.473-1.667$ & 0.711 \\
\hline & Part-time work & 143 & 44.8 & 55.2 & 20.7 & 0.921 & $0.475-1.783$ & 0.806 \\
\hline & Student & 113 & 42.5 & 57.5 & 16.3 & 0.839 & $0.424-1.662$ & 0.615 \\
\hline & Work and study & 161 & 44.1 & 55.9 & 23.2 & 0.896 & $0.467-1.721$ & 0.742 \\
\hline & Unemployed/other & 47 & 46.8 & 53.2 & 6.8 & 1.000 & & \\
\hline
\end{tabular}


Table S2: Predictors of 'double dropping' among those who used ecstasy pills and/or capsules at the last festival (multivariable logistic regression- complete case analysis)

\begin{tabular}{|c|c|c|c|c|}
\hline \multirow{2}{*}{ Variable } & \multirow{2}{*}{ Level } & \multicolumn{3}{|c|}{ Multivariable } \\
\hline & & AOR & $95 \%$ CI & $P$-value \\
\hline \multirow{5}{*}{ Age } & 16-17 years old & 2.336 & $0.949-5.752$ & 0.065 \\
\hline & 18-19 years old & 2.478 & $1.105-5.559$ & 0.028 \\
\hline & 20-21 years old & 0.988 & $0.438-2.231$ & 0.977 \\
\hline & 22-25 years old & 0.691 & $0.303-1.579$ & 0.381 \\
\hline & 26 years and over & 1.000 & & \\
\hline \multirow{2}{*}{ Gender } & Male & 2.272 & $1.487-3.471$ & $<0.001$ \\
\hline & Female & 1.000 & & \\
\hline \multirow{2}{*}{ State } & WA & $\#$ & & \\
\hline & VIC & H & & \\
\hline \multirow{3}{*}{ Ecstasy form } & Pills and caps & 2.714 & $1.540-4.782$ & 0.001 \\
\hline & Pills only & 1.830 & $1.098-3.050$ & 0.020 \\
\hline & Caps only & 1.000 & & \\
\hline \multirow{4}{*}{$\begin{array}{l}\text { Frequency of general } \\
\text { ecstasy use }\end{array}$} & 1/week & 7.057 & $3.072-16.211$ & $<0.001$ \\
\hline & $1 /$ month & 4.056 & $2.004-8.210$ & $<0.001$ \\
\hline & Every few months & 3.313 & $1.640-6.692$ & 0.001 \\
\hline & $1-2 /$ year & 1.000 & & \\
\hline \multirow{3}{*}{$\begin{array}{l}\text { Total recent festivals } \\
\text { attended }\end{array}$} & $1-2$ & 0.973 & $0.577-1.641$ & 0.919 \\
\hline & $3-4$ & 0.978 & $0.594-1.608$ & 0.929 \\
\hline & 5 or more & 1.000 & & \\
\hline \multirow{3}{*}{$\begin{array}{l}\text { Favourite festival genre was } \\
\text { electronic dance music }\end{array}$} & No & 0.703 & $0.438-1.129$ & 0.145 \\
\hline & No favourite genre & 1.044 & $0.586-1.862$ & 0.883 \\
\hline & Yes & 1.000 & & \\
\hline \multirow{3}{*}{ Festival type } & One day & 0.618 & $0.382-0.997$ & 0.049 \\
\hline & Inconsistent selection & 0.638 & $0.247-1.636$ & 0.636 \\
\hline & Multi-day & 1.000 & & \\
\hline
\end{tabular}

Model $\chi^{2}(16)=99.515, \mathrm{p}<0.001$. Adjusted R square $=0.175$ (Cox \& Snell), 0.237 (Nagelkerke). Hosmer-Lemeshow goodness of fit test, $\mathrm{p}=0.423, n=516$. 